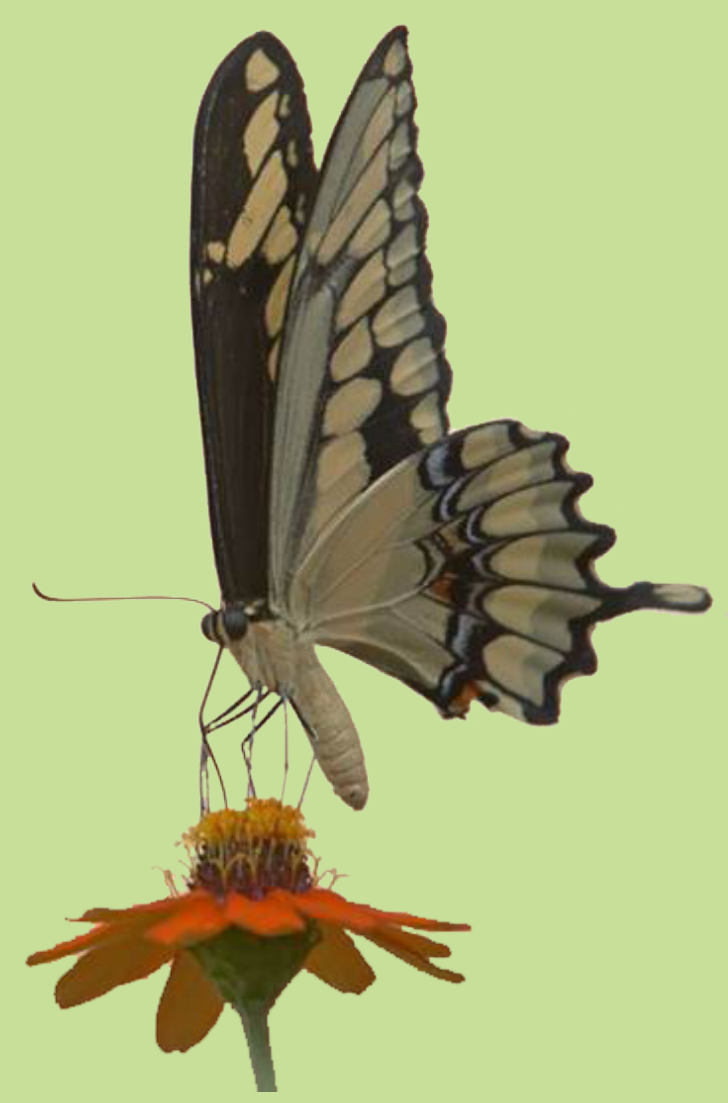

\title{
National Accounting, Global Warming, and other Challenges for Long-term Economic Forecasting
}

Erich W. STREISSLER

KIOES Opinions 4 (2015)

KIOES Opinions are published by the Commission for Interdisciplinary Ecological Studies (KIOES) of the Austrian Academy of Sciences (ÖAW). KIOES publishes current opinions of its members and staff related to topical subjects on an irregular basis in KIOES Opinions. The target audience includes scientists, policy makers and the public. Opinions expressed in this article are solely those of the author, and they do not necessarily reflect in any way those of KIOES or ÖAW.

\section{Oustrian Academy}

More information about KIOES and download of KIOES Opinions at http://www.oeaw.ac.at/kioes 


\section{National Accounting, Global Warming, and other Challenges for Long-term Economic Forecasting}

\author{
Erich W. STREISSLER ${ }^{*}$ \\ * Austrian Academy of Sciences \\ Dr. Ignaz Seipel-Platz 2, 1010 Wien
}

Received: 15.12.2014, published online: 09.01.2015
Erich W. Streissler was born in Vienna, Austria, graduated as Dr. iur. from Vienna Law School and is now Professor Emeritus of Economics, Econometrics and Economic history at the University of Vienna. He was distinguished Austrian Visiting Professor at Stanford University and frequently at Oxford University. He is a member of the Bavarian, the Hungarian and the Austrian Academy of Sciences.
I

Scientific measurements are normally a good empirical basis even for long term forecasting. But unfortunately this is not the case for economic forecasts of average rates of aggregate economic change. This is so for three main reasons.

First, national account statistics have been standardized since about half a century by the United $\mathrm{Na}$ tions; but these statistics are extremely short run in nature and there is no agreed standard procedure for correcting mistakes that become manifest already after one year or in some cases even after only half a year.

Secondly, precise estimations are only possible for commodities with market prices, i.e. for at best one sixth of the entire gross domestic product. Estimates can be calculated only for these marketable commodities, both in nominal values (i.e. values including inflation) and also in real values (i.e. market values corrected for inflation). But in developed economies between some 40 and up to $57 \%$ (in case of France) of all national products are provided by governments. And the cost prices assumed for services supplied by governments may be quite different from (most probably higher than) what prices would be if the services in question were provided in competitive markets. This error is small, however, compared with estimation of government productivity changes, i.e. the calculation of real prices for government services: In the 1950s, government productivity change was estimated most laboriously by Solomon Fabricant, and estimated as one percent a year. And this estimate has been used in the developed world everywhere. It would be somewhat heretical to suggest that at present government services no longer show such a productivity increase of one percent a year, because by now there is in many countries strong political pressure to increase public salaries, but little pressure to increase public service productivity at all (if not even to lower it). Public salaries are no longer an indication of public services rendered. The most interesting problem occurred in the case of France already in the early 1960s. French authorities simply declared that in France public service productivity increased not by $1 \%$, but much rather by $3 \%$ annually. Thus, estimated average French real income growth rates jumped up by about three quarters of a percentage point of GDP each year and a marvellous economic growth increase of France resulted. Much of growth accounting is thus merely ideologically biased guesswork.

The third difficulty is that even in markets monopoly or oligopoly prices can be kept at insupportably high levels for considerable periods, resulting in an excessively high social product - which, as already said, will usually never be corrected downward. Such prices can be set far from equilibrium prices for long periods, in particular in sectors of political interest. A vast number of people are interested in such excessive market prices for advertising and other marketing reasons; to doubt such market prices, which later prove false, is once more thought to be a dangerous "heresy": one simply must not cast such doubt. 
The most notorious case was the faulty evaluation of bank credit for politically motivated house purchases by indigent US citizens in 2005 to 2008 .

To sum up this point: National income statistics are not at all objective, but can be cast in doubt in very many different ways. Apparently objective basic economic figures are not much different from politically motivated propaganda, the true nature of which is realized only by few observers - as with all good political propaganda.

\section{II}

"Finance, like any other industry, is chiefly regulated by people taking responsibility for their actions" wrote The Economist, March $29^{\text {th }} 2008$, p. 17, when the recent, above all US American, financial crisis with the near bankruptcy and forced "rescue" of the banking house Bear Stearns started to become critical. The statement is highly misleading, however, as in recent years - in contrast to 150 or 100 years earlier - The Economist tends to be far too optimistic. Again and again, governments nowadays assume what should be the financial responsibility of private people, i.e. they heavily subsidize financial markets, eventually at the domestic taxpayers' cost. To a large extent, finance is no longer regulated privately! The quoted article continues: "The Fed has signalled that it will now [i.e. by March 2008] stand behind investment banks like Bear, and it has agreed to provide emergency lending to them for the first time since the Depression", i.e. since the 1930s. But this was not the end: "Fed" financing was repeated again and again, at near zero interest rates as cost. The recent Great Crisis proved very costly for American and also for European taxpayers. But if emergency costs rise too high, governments will even go bankrupt, a bankruptcy that is always voluntary, as no international law enforcement against sovereign states exists. Since August $1^{\text {st }} 2014$ Argentina, which had gone bankrupt to the highest ever degree in 2001-2002 by agreeing to pay only $30 \%$ of its international debts (while $50 \%$ payment in international bankruptcy cases had been usual up to then) has been in the throes of a second international bankruptcy by not paying a sum due according to a valid US debt judgement. The pressing question now is, as the USA is constantly increasing its sovereign debt and at hardly diminished rates: When will the United States declare (some sort of) bankruptcy? At present, there are so many influential agents - banks in particular - interested in overestimating national incomes that seemingly objective measurements result in officially maintained lies.

In the critical year 2008 the USA had one of its largest yearly current account deficits of (according to The Economist, March $29^{\text {th }} 2008$, p. 110) 738.6 billion dollars or $4.7 \%$ of its then GDP. (In 2006 and 2007 this deficit had been relatively even higher rising up to $6.5 \%$ of its then current account.) This 2008 deficit had been financed to about one third each by Germany (256.7 billion dollars), by China (249.9 billion dollars [2006 figure]) and by Japan (214.7 billion dollars) - their surpluses in sum with 721.3 billion dollars slightly less than the US deficit. Those three current account surpluses were then the world's largest.

At present the US has still by far the largest current account deficit, though with now (The Economist, September $6^{\text {th }} 2014$, p. 84) 405.9 billion dollars it is nominally only $55 \%$ of that of 2008 . It is now financed to more than $64 \%$ by Germany with 262.9 billion dollars current account surplus, nearly the same as in 2008 , and secondly to $40 \%$ or 163.6 billion dollars by China, nominally only two thirds as high as in 2008. In the meantime, Japan has dropped out of substantial international finance. The third and fourth largest international current account surplus contributions are now provided by Saudi Arabia (132.9 billion dollars) and Switzerland (105.4 billion dollars), these two with the only positive current account contributions of more than 100 billion dollars. (In 2008, Saudi Arabia had with 98.9 billion [figure from 2006] kept just below 100 billion.) Both in 2008 and now in 2014 the second largest current account deficit (and the only one in excess of -100 billion dollars) was engendered by Britain: according to the two issues quoted of The Economist -129.4 billion dollars in 2008 and -117.7 billion in 2014 .

The USA persistently simply ignores the relevance of its current account deficits. But at best any Austrian should know from Raimund's tragicomedy Der Verschwender (modelled after the bankruptcy of the Viennese court banker Count Fries), that in the long run one cannot spend more than one has or earns, even though for some time everybody loves to give credit to a spendthrift. One can often hear that at present the whole world loves to give credit to the USA, but this international credit giving to the USA, which has gone on for 35 years now (since 1980 with 
the sole small exception of the year 1991, the year of the first Iraq war), cannot go on indefinitely. Already, the USA is rapidly approaching the relative international public indebtedness of Italy (Italy now having a debt of $135 \%$ of one year's GDP). The USA is now annually increasing its international indebtedness, as already stated, by 405.9 billion dollars on current account, and that is nearly four times more than the next international debtor, Britain, with, as stated, additional 117.7 billion.

If one adds up the yearly current account deficits the US deficits alone amount to about $40 \%$ of all the current account deficits in the world, which is huge - though still somewhat smaller than around 2005, when the US current account deficit was about two thirds of the world's deficits. Relatively speaking, the USA now shows an annual GDP increase of $+2.1 \%$, but a current account (CA) deficit of $-2.4 \%$ of its GP, in sum a net "growth rate" of $-0.3 \%$, in other words a decline. Relatively speaking (though nominally by far the largest) it is at present only the ninth largest deficit accumulator. South Africa comes first on this negative list with $+2.0 \%$ GDP and $-5.4 \%$ CA deficit, together $-3.4 \%$. Next is Turkey with $+3.0 \%$ GDP and $-5.8 \%$ CA deficit, together $-2.8 \%$. Brazil is third with $+1 \%$ GDP, but $-3.7 \%$ CA deficit, together $-2.7 \%$. Argentina comes fourth and is the only country with negative GDP growth as well: $-1.4 \%$ and $-0.9 \%$ CA deficit, together $-2.3 \%$. Relatively much smaller deficit accumulators are Egypt $(+1.8 \%$ GDP, $-2.5 \%$ CA deficit), France (+0.5\% GDP, $-1.2 \%$ CA deficit) and Britain (+3.2\% GDP, $-3.7 \%$ CA deficit); in eighth place is Canada (+2.3\% GDP, $-2.8 \%$ CA deficit).

Once more adding up GDP growth and the frequently relatively very large current account surpluses, the most rapidly growing countries - each with at least $+10 \%$ growth plus current account surplus - are in descending order: Singapore, Saudi Arabia, Taiwan, Switzerland, Norway, Malaysia and the Netherlands. In this growth order Austria (according to The Economist) would come sixteenth with $+1.4 \%$ GDP growth estimate and $+2.5 \%$ current account surplus relative to GDP.

In a longer run view the fact that for the last thirteen years, but especially so since 2001, the US economy has actually been shrinking, is one of the most important reasons why world per capita income, at least in the developed world, is now on average constantly declining. We shall come to this point towards the end of this paper.

According to the Economist publication "The World in 2014", pp. 91-99, estimated 2014 income levels in purchasing power parity terms per capita show Norway to be first in the world with PPP $\$ 70,250$. Hong Kong is second with $\$ 56.240$ per head in PPP terms, and Switzerland third with PPP \$55.720. The USA is fourth with $\$ 54.920$. Qatar is not given and neither is tiny Luxembourg. Singapore comes next with PPP \$49.280. But then as in PPP terms "richest" in EU Europe (apart from Luxembourg) Austria is shown as eighth richest with in PPP terms $\$ 45.340$ per head, i.e. only about $20 \%$ below the USA. Public perception tends to be quite different: the shrinking USA usually being seen as highly flourishing, even if standard statistics show the opposite, the USA actually having declined already for many decades.

\section{III}

Such are the figures where the relative decline of the USA is already astounding, though simply ignored by the USA. But now we come to the many cases where the figures are actually highly misleading, because they are calculated on an extremely short run basis, without subsequent corrections for long run accounting mistakes.

The first major accounting mistake should certainly be common knowledge among statistically informed persons, but strangely enough is not. How are all national accounting figures calculated? They are calculated quite differently from any private accounting framework, both for physical persons and for firms: For these, they have to be calculated according to the amount of money (or its equivalent) actually paid and actually received.

Even in private accounting with long term contracts estimates of future receipts gain in importance; and the financial downswing since the year 2000 significantly started with gigantic accounting errors and the bankruptcy of Enron in December 2000 - a firm that had habitually made wildly exaggerated forecasts of its future receipts and eventually failed even on its pension promises to the tens of thousands of its employees. Of course government bankruptcies of many developing nations, the largest so far being, as stated, that of Argentina, are similar. 
But these private accounting mistakes are still relatively small compared to those in national accounts: they are mistakes of wrong accounting in contrast to standard national accounts, where the mistake is one of simply NO accounting at all. In national accounts, sums of money actually received within one calendar year are added to the sums shown on invoices sent out - perhaps to be received in the future. But whether such invoices that are carried over from the present into the next calendar (= accounting) year are actually paid is never ascertained! Put differently, it is implicitly assumed that all invoices are always fully honoured!

This was a fairly reasonable assumption when international credits were usually granted for very short periods only, but with longer and longer credit lines the assumption became highly problematic. It became a fatal miscalculation for the USA in 2006-2009, when for political reasons large-scale sales of newly built private homes to subprime debtors became a major business: sales at excessive prices and up to $100 \%$ on credit! Of course these debts remained largely unpaid and US national income was overestimated in terms of trillions of dollars. To a much smaller extent other national incomes, in particular Italian and Greek ones, were overestimated for the same reason. Once more the mistake is that national income statistics do not even ask whether invoices carried over from one year to the next are ever actually paid.

The Governor of the Federal Reserve, Alan Greenspan, who had been mainly responsible for these miscalculations, later estimated that worldwide newly built homes had been overvalued by 40 trillion dollars or by two thirds of one year's world national income - in the USA alone by about 17 trillion dollars or about $120 \%$ of one year's US gross domestic product. Calculated over the entire first decade of the $21^{\text {st }}$ century that would be an overestimation of about 9\% (!) a year: Many US houses had been sold - in the vain hope of future price rises - at 110-120\% even of their excessive current price and had then fallen to about two thirds of that price. Even when the price fell soon after it had proved excessive and was actually only about two thirds as large this would yield an overestimation of US GDP of about $6 \%$ a year. The calculated US economic growth rate over the whole first decade of the $21^{\text {st }}$ century was some $2.2 \%$ per year or at most perhaps $2.5 \%$. So just this one correction of taking into account average housing price capital losses per year would reduce the "true" growth rate of the US gross national product to actually a somewhat more than 3\% annual decline in the first decade of the $21^{\text {st }}$ century. And that is only one of the necessary downward corrections! Many others will have to be made as well. The necessary deduction for income overestimation will probably not remain as high as in the first decade after the secular boom period of the 1990s, but it will be substantial, particularly for the USA.

\section{IV}

We come to a third necessary downward correction of the yearly rise (actually: constant decline) in social product. The usual national income forecasts are made on the simplifying assumption that relative prices do not shift over time, which basically means that we assume only one single commodity consumed. This also implies that we assume all different commodities show the same unitary income elasticity and negative unitary price elasticity of demand. But this assumption is extremely far-fetched. Actually, both income and (in absolute value) price elasticities of demand for so called "necessities" are much rather relatively close to zero, i.e. even with relatively falling incomes expenditures on these commodities can hardly be reduced. Necessities rising in price make for real income decline.

These necessities are of three kinds: most important are foodstuffs, second energy supply (especially fuel demand), and third a vital commodity, which, in developed economies, has so far been supplied at extremely low cost and is therefore commonly forgotten in income analyses: the supply of clean water. Let us neglect the supply of services, which in some cases, like telephone calls, can be expanded at virtually no extra cost. If, for Austria and comparable countries, we assume a correctly calculated decline in the value of material product of $2 \%$ a year and no population change - in fact a highly conservative estimate considering the enormous immigration pressures on Austria - then in fifty years' time (which is my forecasting horizon), in 2065, real income per capita would be about one third of what it is now. Around 2005, food consumption in Austria took up about 12.5\% of disposable income, leaving out, however, alcoholic beverages and food consumption in restaurants. With a drop in national income to one third the hardly reducible consumption of food would thus 
require about one third of national income, with a safety margin of say, plus or minus $10 \%$ of the then social product (a safety margin for both smaller or higher income decline than $2 \%$ a year). Mineral oil has increased in price since the year 2005 from about $11 €$ per barrel to about $65 €$, its price being six times as high as nine years ago; and it will increase in price in the future by further leaps and bounds. Even assuming further drastic demand reductions and a changed demand structure (think of alternative energies) fuel demand will have to take a substantial share of total income demand. And the same will be true of water demand, water rapidly becoming more costly every decade, even in Austria with its abundant water supply (by some estimates Austria is third richest in water, worldwide). The Economist, September $27^{\text {th }}$ 2014, said on p. 14: "Householders are scarcely aware that water has a value" and noted for China - and of course not only for China - the need "to price its water properly". Thus in 2065, expenditure on food, fuel and water is likely to absorb one half, certainly not less than $40 \%$, of all disposable income.

In forecasting cost and demand of those three basic necessities, food, energy, and water, we are faced with estimation problems due to the following two simplifying assumptions: Firstly, it is wrong to estimate future real income under the implicit assumption of a constant-over-time price structure of supplies. Certain commodities will become progressively scarcer over time and will therefore rise in price. The most important cases are on the one hand fuel and on the other water. Consumer demand for food can be reduced to some extent, but not sufficiently to offset the price rises likely to occur. So we shall be faced with problems of general impoverishment over time.

The second methodological problem is that for 50-year-forecasts we must not look at the effect of base period quantity weights of commodities in considering the diminution of welfare. Much rather we have to look at the much higher end of period weights of demand for these commodities of growing scarcity. The likely end period weights in 2065 of the demand for food, for fuel, especially mineral oil, and for water (the demand for which is likely to be around one half of total income expenditure of the average income earner for a country like Austria) will imply that real income (leaving services aside) will drastically decli$n e$ in such a typical European country, as well as in North America and Oceania. I leave out of my estimation the real income demand in all less developed countries, because the very long term social changes about to occur in the less developed world are to my mind too difficult to forecast for an economist. I warn, however, that to see the less developed world as only a somewhat poorer USA is an unsupportable US-centred perspective.

Gerhart Bruckmann has reminded me that already decades ago Oskar Morgenstern, in a well-known survey, estimated that national accounts are at best up to plus or minus three percent correct. Nowadays with increasingly long-term accounting problems this error tends to be substantially larger.

As errors of calculation are, however, highly correlated over time the rates of change of aggregate values are likely to be in absolute terms less error-prone than these aggregate values themselves.

Even larger errors than in national income accounts are likely to occur in national wealth estimations.

\section{V}

A fourth route for long run economic forecasting is to take foreseeable environmental changes into account. Some economists in the or close to the Austrian Academy of Sciences are conscious of this problem, particularly Verena Winiwarter and in some aspects Alexia Fürnkranz-Prskawetz. But it is good to be explicit on the topic especially of average temperature increase by 2065 .

From about 1900 to 2001 there has been registered an increase in average annual temperature of altogether $0.8^{\circ} \mathrm{C}$ in Europe and North America. Then a pause in the temperature increase occurred, noticeably in Europe. This was due to the Atlantic Ocean temporarily absorbing most of the temperature increase with the consequence, however, that the Gulf Stream, which used to warm much of North Western Europe, by now has a very much reduced effect. This makes parts of North Western Europe even colder than before. The average increase in global temperatures from 1900 up to 2065 is likely to be some 2 to perhaps $3{ }^{\circ} \mathrm{C}$, i.e. a further increase of $1.2-2.2^{\circ} \mathrm{C}$ from now on.

In the Austrian Alps such increase of average temperature by some $2{ }^{\circ} \mathrm{C}$ since 1900 has already taken place, causing vegetation to flourish up to 200 to $300 \mathrm{me}$ - 
ters higher than in 1900 - a similar situation to what it had been some 6000 years ago when "Ötzi" crossed the Austrian Alps. That also means that virtually all the Alps' glaciers will have melted away by 2065 , with the exception perhaps of the Aletsch-glacier.

Higher average temperatures will entail considerable. desertification, already of Southern Europe and especially of Northern Africa. The yield of cereals will therefore decline substantially, with resulting price rises. It is not at all clear whether the then higher temperatures in Northern Russia and in Siberia will be able to compensate such losses and cost increase. Needless to say, desertification will intensify the already serious water shortages.

One more important effect of global warming has to be remarked upon, viz. the increase in the frequency and intensity of hurricanes, storms, and floods over the past quarter century - most noticeable in the Carribean and consequently in the USA. This, by the way, is the only negative effect of global warming that has so far been able to impress itself on US public opinion.

Here we come to one more serious miscalculation or simply mistake - in national income accounting: The negative income effects of natural catastrophes are in standard calculation seen as chance effects, which national income calculations ignore. The costs of repairs of damages, on the other hand, are seen as additional wealth creation. So, curiously enough, though wrongly, weather catastrophes end up as increasing national incomes! Any sensible calculation should register the damages as decreases of net income. That is particularly important in view of the global tendency of weather extremes to increase over time, implying increasing damages, of course, and a further fall of average consumable national incomes in the period up to 2065 .

\section{VI}

A fifth cause of miscalculation of economic welfare is the standard miscalculation of environmental damages, a topic similar to the previous one. Methodologically the problem is once more twofold: Firstly, environmental costs are often classified as income increasing benefits. And secondly, the increase of environmental damages over time is ignored.
But perhaps environmental damages will not increase over time. For in reasonably wealthy economies and I consider only such - public demand for a clean and healthy environment is increasing. This would still mean, however, that higher costs to keep the environment clean and healthy would entail increasing costs over time to keep it so. So if there should be a smaller deduction from wealth due to smaller damages there would be a larger deduction due to the increasing costs of keeping damages low.

To illustrate the problem let us assume that an industrial plant needs a water supply from the main or from a river; or that an industrial plant wishes to emit smoke due to some firing process. With efficient legal and technical controls as to quantity and quality of the respective emissions this need not result in environmental problems. But costs will be higher and net benefits lower. Furthermore, environmental losses will occur in two other ways: firstly, legal control costs are wrongly reckoned as "benefits", i.e. as income, just like the costs of all other government actions. Here we have a first case of governmental action reckoned as a benefit, while actually it is a cost of producing social welfare and as such should be subtracted from the benefit. (To this problem in its more general form we shall come later).

Secondly, many environmental damages have not yet been realised in all their ramifications. E.g. the indirect damages of DDT were not realized for a long time; neither were the long-term damages of atomic bomb tests. These costs cannot be ignored. Once more, true benefits or gains will be known much better at the end of a longer period, i.e. in our case only judged as benefits when viewed from the year 2065 backward, when their true costs have been ascertained.

In case of nuclear power plants the staggering costs of the final disposal of fuel rods are uncertain, with estimates constantly increasing.

Frequently, however, environmental costs of industrial production are not taken into account as social costs: Water taken up for production purposes from a river is allowed to be readmitted as soiled water (or at least partly soiled water) back into the river; and smoke may be emitted as by-product of industrial life. In this case industrial production costs are actually figured too low and the environmental damage is a double one: Calculated cost of production 
is too low (relative to true cost) and because of too low a price of production calculated production benefit is likely to be too high. Such environmentally damaging production can often be maintained only by ignoring true cost: if it were calculated at its true cost it would no longer be profitable - an argument ignoring the optimal total efficiency of production.

Thus in present national accounting standards the costs of environmental damages are wrongly ignored, costs are to quite a large extent miscalculated as too low, and finally benefits are assumed to occur where there are actually none.

\section{VII}

A sixth case of necessary corrections in national income calculation has to do with the common treatment of governmental services. Public services should rightly be treated as mere intermediate products or, to put it differently, as mere costs of providing consumption, investment, or export goods, and should therefore be subtracted from final gains. For "social product" proper is only - in market economies what private individuals are finally willing to pay for.

Gerhart Bruckmann pointed out to me that simultaneously with an increase of social product in the narrow and truest sense so-called regrettables also increase: the cost of police, the cost of necessary tax inspectors, the cost of security guards and so on. Frequently military costs also increase parallel to the increase of the social product proper.

This was a controversial question already at the time when national income accounting was originally developed in the late 1930s. The early theorists of national accounting - Keynes, the eventual Nobel Laureate James Meade, Colin Clark, who was first in estimating national incomes (cited in Keynes' General Theory, p. 102) and the eventual Nobel Laureate S.S. Kuznets - were salaried public servants for at least some of their working time; this may be the reason why it was decided to consider their salaries as remuneration for public services. But this veils a theoretical problem and amounts to some double counting.

Secondly, the price actually received from the final demander (i.e. the eventual private consumer, investor or exporter) is considered when estimating social product. The question is if - with no public provision - some private demander would have been willing alternatively to pay for the respective service, a highly doubtful possibility. Public services are often provided where there is no will to pay privately. Here something is counted as product, which would not have been provided for and paid privately. It is in fact only an exploitative payment in the interest of agents in public authority!

Large parts of public expenditure are, of course, creating private benefits and would in other types of social arrangements have to be provided privately and frequently are provided privately so. This is true above all for expenditures for educational and for health care purposes and for the provision of infrastructure and public utilities. These are clearly part of the social product. But here the question is whether private provision, correctly priced, would not be less costly than (frequently inefficient or monopolistically bloated) public provision of the goods in question. Of course, there are cases, however, where public provision will prove cheaper than alternative private provision: viz. if private provision would generate protected monopoly profits.

An example for the necessity of downward correction for monopolistic profits would be the US health care system, which at the cost of now more than $18 \%$ (tendency: rising) of US national income is very expensive. At that, it does not even cover more than 10 to $15 \%$ of Americans. Thus it is about twice as expensive as the usual 10-12\% European health care expenditure, which covers more or less the total population. The high US health care cost may be due to excessive fees especially of top doctors and also of the health administration officials, as well as the excessively high premiums doctors pay to insure themselves against suits for malpractice in the problematic US legal system.

A further inefficiency of public provision in the USA which should be corrected downwards when comparing optimal private services with inefficient public ones: The USA produces double the amount of lawyers' services per unit of social welfare, as compared with Europe. This has to do with US tort law, which allows juries to adjudicate damages. Gynaecologists, e.g., are in fact frequently no longer insurable for damages in the USA: About $0,05 \%$ of women die in childbirth, without any fault of the medical attendants; but in the USA the lawyers for the aggrieved 
families will always persuade a jury that the treating doctor was at fault and in addition would gain them huge damages, their own legal fees also having to be paid by the doctors. In the USA excessive fees for health provision and in addition excessive fees of lawyers in inefficient legal procedures relating to health services unnecessarily overvalue health costs in national income calculation and should be corrected downwards.

This touches a further problem: In public accounting, pension payments, both private and public and also subsidies to individuals or firms, are correctly considered as mere transfers between individuals, transfers that do not increase social welfare. (The effect of income redistribution between persons, even if sometimes increasing the sum of total utilities, is never treated in social accounting.) But many public salaries are actually subsidies to individuals without any official duties. If so, it is wrong to include them in national incomes. Recently, this has occurred to a large extent in Greece. Former Greek governments had created large numbers of additional public jobs, mere sinecures, for people they considered their clientele; and as the parties in government switched, different clienteles profited. As none of those people produced much, their public salaries and pensions have been one of the reasons for the infamous overestimation of Greek social product.

There are many cases of very large governmental expenditure - take the $57 \%$ of social product spent on public account in France - where commensurate public benefits are highly doubtful (in contrast to the private benefits for the recipients).

\section{VIII}

I turn to a seventh cause of declines in national incomes: climate change, above all rising average temperatures, already estimated above to be (from 2005 to 2065) of the order of magnitude of $1.2-2.2^{\circ} \mathrm{C}$. I have already touched upon the topic above, but will here try to cover more of the relevant aspects.

Typically, natural scientists focus on longer run climate change effects, while economists tend rather to belittle negative climate change forecasts, because of their usually very short run perspectives. With respect to climate change, even economists, however, will very soon have to change to longer run considerations.

A first effect of average temperature increase will be in the more temperate regions of the northern hemisphere, i.e. particularly in Europe, where summer temperatures will rise and hotter periods will be more bunched together. Precipitation will be more unevenly distributed over the year and, as mentioned already, damaging storms will increase. This will lead to less vegetation of use to human beings and thus to price increases: As mentioned above, from 2005 to 2014 European food prices have already risen on average by $2 \%$ more than industrial ones.

A second effect will be due to a greater need for renewable fuels with the exhaustion particularly of cheaper exploitable deposits of mineral oil and coal. In temperate zones, more and more wood will be needed for firing. This means that deforestation, up to recently still increasing, will have to be stopped and the amount of forest cover will increase. This is seen particularly in Austria, one of the relatively densely forested rich countries. Increasing forest cover will slightly slow climate warming. But it will have the effect that less of the soil will be available for pastures and grain production - with the usual consequence of rising food prices.

Furthermore a considerable degree of warming of the oceans has to be expected. A substantial amount of the climate warming effect will go less into the atmosphere, but rather into ocean warming. This will make fishing "harvests" smaller and more costly: Many of the nutritious larger fish live in relatively cold waters, but these will heat up. Warmer oceans favour the development of more algae. But algae are not readily consumable by human beings and also tend to diminish free oxygen in the sea, thus causing living conditions for fish to deteriorate.

Advocates of "fracking" and like processes maintain that the progressive exhaustion of extractable mineral oil is much exaggerated: Additional finds of shale oil and of natural gas should be ground for optimism that oil production can go on as before.

But total exhaustion of a resource has always been and still is an unrealistic and uneconomic idea: What really happens is a progressive increase of the cost of extraction over time. Total exhaustion will never occur, because at some point extraction becomes too costly, relative to alternative energies. Further 
mineral oil deposits have to be extracted ever deeper down in the ocean - now deeper than 5000 meters below the sea surface; and the same is true for the extraction of shale oil and mineral gas below the land surface. Progressive cost increase over time implies that more and more resources would have to be employed in the extraction of scarce mineral fuel - resources that are missed in other employments. This will eventually limit the demand for oil.

Of course, it is not yet clear in detail what further "scarcities" substantial global average temperature increases of $1.2-2.2{ }^{\circ} \mathrm{C}$ will bring about in the coming fifty years. But they will certainly lead to cost and price rises due to exhaustion of certain resources, thereby limiting economic growth and making it negative in effect: Progressive climate change will thus make all of us progressively poorer!

\section{IX}

My final problem is the increasing level of international credits with doubtful returns, which more critically could be termed gifts or near gifts by public authorities, especially since the year 2000 .

From 1994-1999, the world experienced its fifth Kondratieff-Peak (since 1785) - Kondratieffs being the forty to sixty year periods between peaks of innovations and correspondingly of investment. In the USA and Europe this fifth peak showed GDP growth rates of $5 \%$ and more. As the relevant innovations were capital saving ones there were surprisingly little further investment needs after the end of the boom in the year 2000 (with the first great bankruptcy, that of Enron in December 2000). So the world suddenly switched from high investment needs to surplus world saving intentions and that from 2000 to still now in 2014. The saving surplus actually creates a second kind of gift.

However, especially after the boom years of 1994 to 1999 with increasing investment opportunities the sudden disappearance of such opportunities was generally not believed. In particular, large banks promised continuing investment opportunities, which were, however, no longer there. Interest rates should have fallen immediately, because there was a world excess of saving intentions. But they fell far too slowly - although by now they are reaching near zero in Germany and in other EU countries economically close to Germany. As market interest rates fell much too slowly banks wrongly believed they were earning (overestimated) interest on doubtful financial investments.

In the US private sector, too, there reigned all sorts of mistaken beliefs. During the 1994-1999 boom, private saving nearly stopped because people wrongly believed they were getting richer from what were actually only temporary stock market gains (stock market assets being held in the USA by about one half of US private households). And some eight years later US householders wrongly believed they were getting richer without actual saving by equally illusory house price increases. The savings rate of the US private sector fell to minus (!) 2\% in 2006 and 2007.

Alan Greenspan, Federal Reserve Governor from 1986-2006, did his utmost to maintain public illusions about the economic and financial situation. As a Republican he tried to save the standing of Republican US President Bush II when unexpectedly two months after his inauguration a recession hit already in March 2001. Greenspan drastically reduced the Federal Reserve interest rate in 2001 from $6.5 \%$ to $1.75 \%$ and soon after to $1 \%$. It was he who initiated near zero central bank interest rates, which since then have become common and are actually nothing but subsidies for large banks; or in other words public gifts to private banks.

A government campaign encouraging a general spending spree after the "9/11" attacks on the USA plus Greenspan's "policy" assured the re-election of Bush II in 2004. So for 13 years now and worldwide, we have had very low central bank interest rates, which actually are largely gifts.

For the USA the special feature was that already President Clinton had initiated a policy to increase the percentage of Americans owning their homes, extending the percentage of house owners from about 60 to around $69 \%$ of householders. Particularly under Greenspan in the final years of this program (20052007) down payments were reduced to historically unusually low $2 \%$ of the purchase price and eventually even to zero (!) percent with loans even exceeding this price. Large chunks of these bad debts were financed internationally by European, especially German credits to banks, so that the huge US debts had an international dimension. The dismantling of these debts from 2008 onwards meant that large 
chunks of such debts were actually taken over by the US government, thus providing gifts to the debtors. Some of the largest banks, e.g. CitiBank, were saved by government interference, at high cost to the taxpayer. Finally, government measures caused the richest $1 \%$, in fact above all the richest $0.1 \%$, of Americans to become even richer. (An important article by the British economist A.B. Atkinson has documented the staggering increase in US income concentration, especially among financiers and bankers.) The median income earner in the USA (50\% being higher, 50\% lower) has actually lost altogether some $2-3 \%$ within the last 30 years, people in the lower half of the income distribution losing even more, a large number of Americans now having negative assets, and only the top earners gaining.

In recent years, several German government loans were in effect made at zero interest. In effect, this turns them into gifts - possibly involuntary gifts, as e.g. when the then French Minister of Finance, Madame Lagarde, declined to pay interest on a German public loan, pleading "force majeure". Gifts, however, do not fall under commercial transactions and are therefore not part of national income. If Germany up to recently was making large loans in effect for free, this actually meant that its national income, with at present a current account surplus of $7.2 \%$ of GDP, was up to perhaps $5 \%$ of its assumed total every year actually smaller than estimated! And when the European Central Bank was making interest-free loans to Greece, repayable only after thirty year duration that was evidently once more a mere subterfuge, as no one can know what happens on financial markets over a period of thirty years. In all probability, these "loans" may turn out to have been gifts.

So, in the Western World we can now observe that one of the activities of governments and international financial authorities is direct and indirect giving of gifts on a huge scale - only thinly covered up by easily discernible accounting tricks.

On an international scale the main creditor since the year 2000 has actually been China with its huge savings, which come close to one half of ifs social product. Of late, though, China too has more and more difficulties in receiving positive real returns on the credits it gives.

\section{$\mathrm{X}$}

I recapitulate my argument. Since about 100.000 years, human beings have been able rationally to consider longer run economic perspectives. Thus they should be able to be better long run forecasters than even apes. But the exact opposite is the case. Typically, the USA forecasts an average economic growth rate of GDP of $+2 \%$ a year, higher than in Europe, for which the US estimates growth rates e.g. for Germany $+1 \%$ and for France and Italy zero. Correctly measured and including international debts, it should be exactly the opposite: Corrected social product is falling most rapidly in the USA, while only less so in Germany and Austria, but in the long run here, too, social products will fall on average: mainly because of climate change and concomitant increases in the cost and prices of water, energy, and basic foods. Since about a quarter century, major political entities like the USA have been using man's ability to foresee and to forecast for purposes of self-interested propaganda, by ignoring or falsifying glaring facts. Technically this has been managed by using overoptimistic short run statistics and by sweeping realistic longer run doubts and negative developments under the carpet. Economic lies have become rather too common. 